\title{
Economy of arm autotomy in the mesopelagic squid Octopoteuthis deletron
}

\author{
Stephanie L. Bush ${ }^{1,2,3, *}$ \\ ${ }^{1}$ Midwater Ecology Lab, Monterey Bay Aquarium Research Institute, Moss Landing, California 95039, USA \\ ${ }^{2}$ Department of Integrative Biology, Valley Life Sciences Building, University of California, Berkeley, California 94720, USA \\ ${ }^{3}$ Present address: Department of Biological Sciences, Center for Biotechnology and Life Sciences, University of Rhode Island, \\ Kingston, Rhode Island 02881, USA
}

\begin{abstract}
Remotely operated vehicles (ROVs) wer e used to obser ve and collect the meso pelagic squid Octopoteuthis deletron Young, 1972. I documented numer ous individuals with shortened, blunt-ended arms and regenerating arm-tips, which may be indicative of ar $\mathrm{m}$ autotomy, i.e. the jettisoning of a body pat as a defense. To test the hypothesis that $O$. deletron is capable of arm autotomy, laboratory investigations and an in situ experiment using ROVs attempted to induce autotomy. I looked for autotomy fractur e planes in histologically sectioned ar ms. $O$. deletron is capable of arm autotomy, but it requires traction to occur. O. deletron has numerous places where an arm can sever; arm breakage always occurred immediately proximal to the point of interaction, minimizing tissue loss, and demonstrating 'economy of autotomy'. Despite the fact that this species can autotomize an arm anywhere along its length, only a few well-defined fracture planes were found in our histological sections, indicating that autotomy pr obably occurs via loss of tensile strength during a defensive interaction. In $O$. deletron, an autotomized arm usually thrashes and the ter minal arm photophore bioluminesces - whether a steady glow, flashing on and off, or both-which could be an impor tant part of predator distraction associated with autotomy in dark, mesopelagic waters. O. deletron is the first squid reported to autotomize its ams, the only cephalopod known to be capable of economy of autotomy , and is one of ver y few species known to use attack autotomy, whereby a predator is grasped by a body part that is subsequently autotomized.
\end{abstract}

KEY WORDS: Cephalopod · Autotomy · Economy of autotomy · Attack autotomy · Bioluminescence · Defense $\cdot$ Mesopelagic

\section{INTRODUCTION}

Anti-predator behaviors ar e categorized as primary or secondary defenses according to when they are enacted. Primary defenses operate regardless of predator presence and ar e often per manent features of an organism's morphology or ecology - such as cryptic coloration or noctur nal activity-thereby decreasing the likelihood of detection (Edmunds 1974, Endler 1981). Secondar y defenses ar e performed when an organism has perceived a potential predator (Edmunds 1974). These defenses decr ease the chance of a successful attack and include startle, counter-attack, protean (erratic) behavior, playing dead (thanatosis), fleeing, and autotomy.

Autotomy is the defensive loss of a body part that is instigated by nervous control and occurs at a fracture plane (Fleming et al. 2007). The jettisoned body part, which often moves vigorously after autotomy, draws a predator's attention away from the potential prey organism, increasing its probability of escape (Edmunds 1974). Autotomy is typically a last-r esort defense in predator-prey interactions since it involves the loss of tissue (Wilkie 2001, Maginnis 2006, Fleming et al. 2007). 
The loss of a body part or parts through autotomy may result in a number of costs, including decreases in: locomotor efficiency, sexual recognition and selection, ability to escape, foraging and prey handling, and fecundity (Maginnis 2006, Fleming et al. 2007, Wrinn \& Uetz 2008, Lawr ence 2010). In addition, the ener gy expenditure required to regenerate lost tissue can reduce fitness (Naya et al. 2007). Autotomy nonetheless occurs in a wide range of vertebrate and invertebrate taxa, and these multiple independent evolutionar y occurrences point to the effectiveness of defensive autotomy (Maginnis 2006, Fleming et al. 2007).

An autotomy fracture plane can be either a str ucturally weak anatomical breakage point, or a potential breakage site that experiences a loss of tensile strength during autotomy (Wilkie et al. 1990, Wilkie 2001, Fleming et al. 2007). A fracture plane allows for a clean br eak that minimizes trauma and speeds healing (Wilkie 2001). Most species r equire external resistance, such as a pr edator's grip, for autotomy to occur (Fleming et al. 2007). Some or ganisms require a force equivalent to their own mass or more to autotomize (Fleming et al. 2007). The threshold for breakage varies between species, individuals, and even limbs within an individual (Fleming et al. 2007).

Among cephalopods, some shallow-water octopuses autotomize and regenerate arms (Ward 1998, Norman \& Finn 2001, Norman \& Hochberg 2005, Hochberg et al. 2006, Huf fard 2007). Ameloctopus litoralis autotomizes at a pre-formed fracture plane near the base of the ar m (Norman 1992, Nor man \& Finn 2001). Other octopuses also have a specific section along the arm (e.g. between Suckers 4 and 7 in Abdopus 'sp. Ward'), where autotomy occurs, but no fracture plane is evident prior to this (Noman \& Finn 2001). InAbdopus capricornicus, an autotomized arm can thrash for more than an hour post-autotomy (Nor man \& Finn 2001). Though the rate of regeneration likely depends upon temperature, nutrient availability, and the animal's life-stage, ar $\mathrm{m}$ regeneration was $\mathrm{r}$ eported to take 10 wk for Abdopus 'sp. Ward' and, wher e known, 2 to 3 mo for its congeners (W ard 1998, Norman \& Finn 2001, Norman \& Hochber g 2005). The males of pelagic octopuses in the family Ar gonautoidea jettison their sper matophore-laden mating ar $\mathrm{m}$ (hectocotylus) and pass it to a female during mating (Naef 1923, Roper et al. 1984, Nor man et al. 2002). While this is not performed in a defensive context and therefore not consider ed autotomy, members of the argonautoid genus Tremoctopus are able to jettison portions of their web (Thomas 1977). Given the evolutionary distance between near -shore, benthic, and pelagic octopuses that autotomize or jettison body parts, this behavior must have evolved multiple times among cephalopods (Norman \& Finn 2001, Str ugnell et al. 2006). Autotomy has not been previously reported in squids, cuttlefishes, Vampyromorpha, or nautiluses.

Squids of the deep-sea genus Octopoteuthis have feeding tentacles as paralar vae, but lose them at an early life-stage as they begin an ontogenetic descent into deeper water (Young 1972, Sweeney et al. 1992). Each of the squids' 8 ar ms has 2 series of hooks that alternate along the length, with a few small suckers between these hooks and a lar ge, terminal photophore (Young 1972). These photophores are approximately equal in size among the arms of an individual and increase in length along with ar m growth. Netcaught specimens commonly have blunt-ended ar ms of unequal lengths or $\mathrm{r}$ egenerating arm tips (Young $\&$ Vecchione 2009). An arm cut off of a moribund $O$. neilseni immediately began to thrash, and the am-tip photophore was luminescent ( $\mathrm{Y}$ oung \& V ecchione 2009). Additionally, an O. megaptera observed in situ by a ROV was missing a few of its am-tips (Vecchione et al. 2002). These observations led to the hypothesis that Octopoteuthis spp. are capable of arm autotomy (Young \& Vecchione 2009). However, arm loss due to physical damage from nets or sub-lethal predation could not be ruled out, and no cases of arm autotomy were observed directly. I tested the hypothesis that $O$. deletron, which inhabits meso pelagic depths (300 to $1000 \mathrm{~m}$ ) in the easter $\mathrm{n}$ North Pacific (Young 1972), is capable of arm autotomy by under taking in situ observation and experimentation, laboratory manipulations, and histological sectioning.

\section{MATERIALS AND METHODS}

\section{Submersible observations}

I made dir ect in situ observations and r eviewed video footage from previous dives of 3 ROVs ('V entana', 'Tiburon', and 'Doc Ricketts') owned and oper ated by the Monter ey Bay Aquarium Resear ch Institute. Footage was primarily obtained within or just outside Monterey Bay, California; however, additional observations were made off the coast of Oregon. Each vehicle was equipped with a high-r esolution, broadcast-quality video system that allowed us to make detailed observations of an organism at a distance of 5 to $10 \mathrm{~m}$. An onboard variable ballast system allowed the ROV to be trimmed to neutral buoyancy . These features allowed us to examine Octopoteuthis deletron individuals for breaks along each arm. Regeneration 
was observed as partial regrowth from a blunt end, photophores that wer e smaller than those of other arms, or distal hooks that wer e disproportionally smaller than proximal hooks. While cephalopod species descriptions include an ar $\mathrm{m}$ formula describing the relative length of arm pairs, due to collection damage, no ar $\mathrm{m}$ formula was $\mathrm{r}$ eported for $O$. deletron (Young 1972). Therefore, relative arm length was not used to determine whether autotomy, regeneration, or both had occurred in the absence of relatively smaller portions of an arm, hooks, or photophores.

\section{Laboratory observations}

Each ROV had a number of collection devices designed to minimize disturbance to specimens of interest. Octopoteuthis deletron individuals were collected for laboratory observations at sea and ashor e. I used arm touching, holding (without pr essure), pinching (with pressure), pulling, dragging ar $\mathrm{m}$ hooks along pieces of Velcro, and electric shocks from a 6V battery to attempt to instigate autotomy. The bioluminescence output of a terminal photophore was measured $(\mathrm{n}=1$, QE65000 Spectrometer, Ocean Optics Inc.).

\section{Histology}

One, 4, or 8 ar ms from 15 Octopoteuthis deletron specimens were sectioned to look for fractur e planes ( $\mathrm{n}=82$ arms). As controls, arms were sectioned from 1 Chiroteuthis calyx, 1 Gonatus sp., and 1 Vampyroteuthis infernalis, none of which are thought to autotomize their arms. All material was preserved in 10\% formalin and ar ranged in cassettes for paraf fin embedding, longitudinal sectioning, staining with hematoxylin and eosin, and slide-making. Each slide was scanned under a dissecting or compound microscope for fracture planes, such as a weak point within the longitudinal muscles as in Ameloctopus litoralis (Norman 1992), and in stances of r egeneration not visible from gross morphological assessments.

\section{In situ experimentation}

In a previous study, I observed several individuals grabbing (counter-attacking, $\mathrm{n}=23$ of 76 ; Bush et al. 2009) the ROV, though none of these instances $r$ esulted in arm autotomy. I hypothesized that autotomy during counter-attack requires grasping by the ar $\mathrm{m}$ hooks to provide resistance and that the ar $\mathrm{m}$ hooks are unable to attach to the metal components of the ROV. I tested this hypothesis by mounting a $200 \mathrm{~mm}$ laboratory bottle-brush onto the swing arm of a ROV ('Ventana' or 'Doc Ricketts'). The vehicle was manipulated to touch an Octopoteuthis deletron individual $(n=7)$ lightly on the arm/s or mantle in order to instigate a counter-attack. Control tests were performed with 7 Chiroteuthis calyx, 9 Galiteuthis phyllura, 9 Gonatus spp., 1 Histioteuthis heteropsis, 1 Japetella diaphana, 15 Taonius borealis, and 1 Vampyroteuthis infernalis. All of these species co-occur with $O$. deletron at mesopelagic depths off Central California, and none are thought to autotomize ams.

\section{RESULTS}

\section{Submersible observations}

I observed 84 individual Octopoteuthis deletron during ROV dives fr om June 2003 to October 2010 and reviewed recorded footage of 21 individuals from previous dives (total $n=105$ ). Some obser vations were limited by viewing distance; ther efore, I was only able to make clear deter minations for 62 individuals. Of these, 17 (27\%) had from 1 to 8 bluntended, foreshortened arms. These 17 individuals had

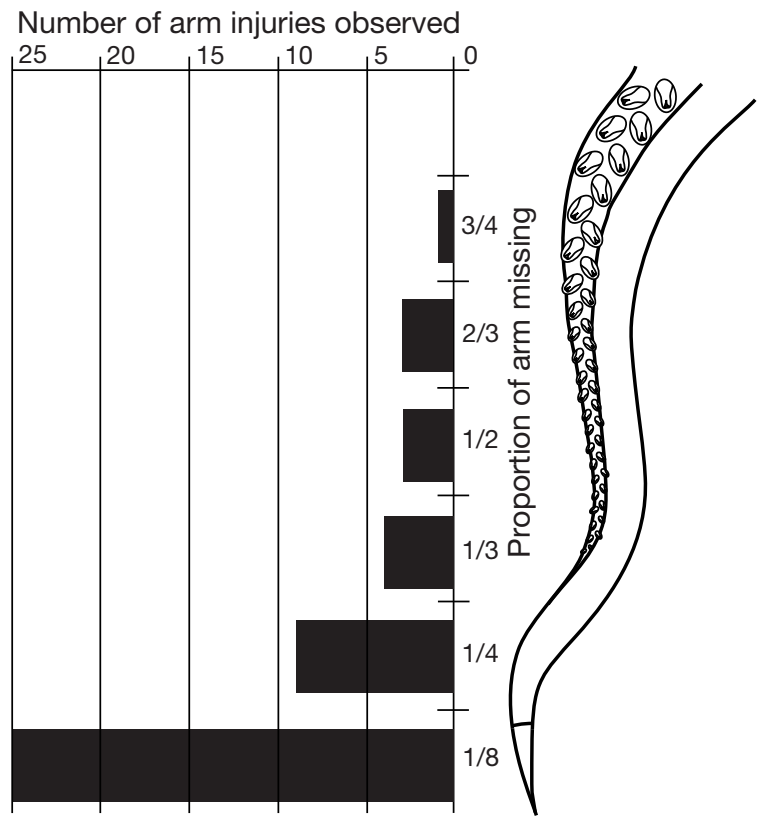

Fig. 1. Octopoteuthis deletron. The number of ar $\mathrm{m}$ injuries observed $(n=47)$ plotted by the pr oportion of arm missing. The proportion missing was deter mined by comparing the relative length of the injured arm to the lengths of the uninjured arms. We assumed that uninjured $O$. deletron arms are approximately equal in length 
a total of 47 ar m injuries (Fig. 1). Any of the ar ms could have an injur $y$, and no ar ms were found to have more injuries relative to other arms. It was not possible to deter mine if specimens with multiple injuries obtained them during one or mor e interactions. Injuries occurred from just proximal to the terminal photophore to the loss of thr ee-fourths of the arm (Fig. 1). Loss of the arm tip, including the terminal photophore, was the most common type of injury ( $n=25$ of 47 injuries, $53 \%$; Figs. 1 \& 2A). In contrast, only 1 individual was missing three-fourths of an arm (Fig. 2B). One ar m was encounter ed slowly sinking through the water column; the squid itself was not seen. The ar $\mathrm{m}$ was missing a small, ir regularly shaped portion of flesh next to a cleanly severed end (Fig. 2C). Nine (of 62, $14.5 \%$ ) individuals wer e actively regenerating arms (Fig. $3 \mathrm{~A}$ to $\mathrm{C}$ ).

During 1 in situ observation, 2 arms of an individual were accidentally sever ed by ROV collection equipment during attempted specimen captur e. These arms thrashed for 15 and $32 \mathrm{~s}$ before going out of the camera's view. In a separate obser vation, an individual released 2 pseudomorphs (a type of ink release that approximates the size of the squid; see Bush et al. 2009) and autotomized an ar $\mathrm{m}$ that thrashed rapidly for $9 \mathrm{~s}$ before going off-screen.

\section{Laboratory observations}

Of the 11 individuals tested, 7 (64\%) autotomized 1 or more arms. Four individuals par tially autotomized an arm, whereby a split occurred from either the oral or aboral side, but did not fully sever; 1 of these individuals later fully autotomized the ar $\mathrm{m}$ at the same spot. An Octopoteuthis deletron arm partially or completely autotomized only at the point of stimulation. Autotomy never occurred within the terminal photophore. Autotomy requires voluntary nervous control which was only elicited when resistance occurred. Two autotomy mechanisms were induced: (1) an arm is grabbed by an exter nal source (i.e. a potential predator), providing the traction for autotomy and (2) the ar m hooks grasp an object (i.e. a potential predator) and their attachment provides the traction for autotomy.

One individual grasped the text ured bottom (rubber topped with fabric) of its holding container with the arm hooks, somersaulted, and r eleased ink as it autotomized part of all 8 ar ms. All the sever ed arms thrashed while the ter minal photophores bioluminesced steadily for $\sim 10 \mathrm{~s}$. The autotomized sections measured 9 to $22 \mathrm{~mm}$ in length (mean $=15.9 \mathrm{~mm}$ ). In
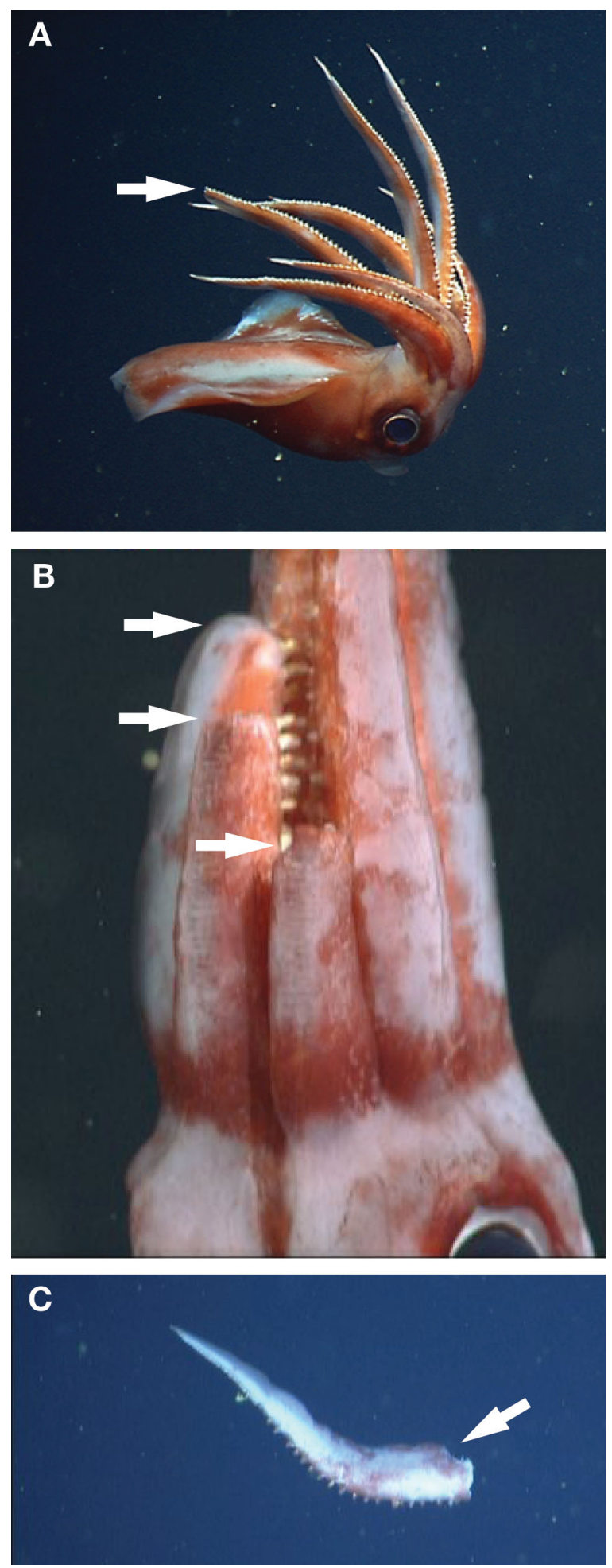

Fig. 2. Octopoteuthis deletron. (A) An individual missing the terminal photophore of Arm LII (arrow). (B) An individual with 3 ar ms autotomized at dif ferent lengths (arrows). (C) Arm found sinking through the water column. Arrow points to the ir regularly shaped location that was missing tissue, proximal to the clean br eak, which was possibly a $r$ esult of autotomy 

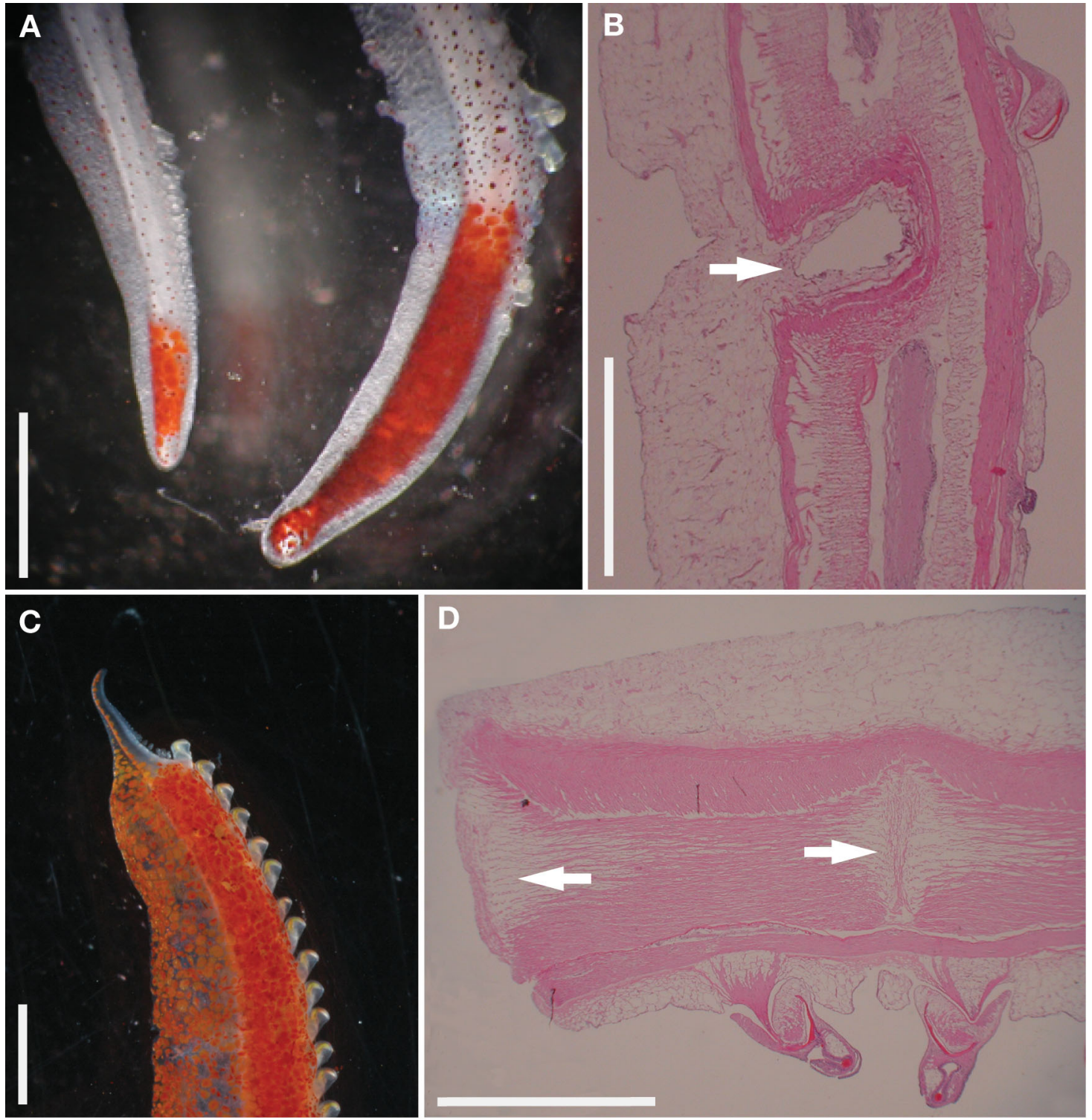

Fig. 3. Octopoteuthis deletron. (A) A regenerating photophore (left) next to a full-sized photophore (right). (B) An example of damage, possibly from a partial autotomy, that has been regenerated (arrow). (C) A previously autotomized arm beginning to regenerate. No terminal photophore is yet present, chromatophores have developed only on the aboral side, and hooks have just begun to form at the proximal end. (D) Two fracture planes (arrows) of an O. deletron arm. The fracture plane on the left is where the arm autotomized; the fracture plane on the right is a point wher e the arm began to, but did not completely autotomize. Scale bars $=5 \mathrm{~mm}$

addition to these longer ar $\mathrm{m}$ sections, 8 shor ter sections ( 1 from the medial por tion of each ar $\mathrm{m}, 2.1$ to $4.0 \mathrm{~mm}$ length; mean $=2.98 \mathrm{~mm}$ ) wer $\quad$ e also jettisoned, but these did not move. Ther e were also 119 arm hooks that had separated fr om arm tissue and were either attached to or lying on the container bottom. The bioluminescence was bright enough to be seen under full laborator y lighting. The maximum spectral output (measured from a different specimen) peaks at $465 \mathrm{~nm}$.

\section{Histology}

Evidence of regeneration was observed at different points along ar ms from 8 of 15 individuals (53\%; Fig. 3A to C). In addition, several ar $\mathrm{ms}(\mathrm{n}=14$ of 82 , $17 \%$ ) were partially separated in 1 or mor e places, usually from the oral (hook-bearing) side of the arm. These may have been the result of partial autotomies such as those that occur red in laboratory observations. Fracture planes were found within 5 to $8 \mathrm{~mm}$ of 
the point at which autotomy had occur red in 2 arms (1 from each of 2 individuals; Fig. 3D). No other fracture planes wer e found. No r egeneration, evidence of autotomy, or fractur e planes wer e found in any other species examined.

\section{In situ experimentation}

When touched by the bottle-brush, an Octopoteuthis deletron would sometimes move quickly away fr om the stimulus, stop, and then maintain its position.

In other cases, counter -attacks by the squid wer e elicited, in which the squid jetted away fom the stimulus, paused with the arms spread to their widest extent, then jetted toward the stimulus, and grasped it. Usually the chr omatophores overlying the ter minal photophores were all contracted when the arms were spread widest, exposing the photogenic tissue (i.e. the photophores were presumably bioluminescent). Most touches by the bottle-br ush were to the ar ms, and when a counter-attack was elicited it was as described above. In cases where the squid was touched on the posterior mantle, the individual flipped around to orient the ar ms toward the bottle-brush and then counter-attacked. Not ever y touch by the bottlebrush elicited a counter -attack, and not all counter attacks resulted in ar $\mathrm{m}$ autotomy; however, all instances that resulted in arm autotomy were preceded by a counter-attack. Five out of the 7 O. deletron I tested in situ autotomized 1 (4 individuals) or 2 arms (1 individual, Video 1 in the supplement at www. int-res.com/articles/suppl/m458p133_supp/) onto the bottle-brush. One of these individuals counter attacked and autotomized an am after being touched by the bottle-br ush once; however, counter-attack and autotomy were not instigated in other individuals until they were touched by the bottle-br ush 10 to 18 times. While some of the 43 individuals of other squid species held onto the bottle-br ush, they never counter-attacked or autotomized an arm.

After autotomy, 3 of the 5 Octopoteuthis deletron jet-escaped, each $\mathrm{r}$ eleasing an ink pseudomorph. The other 2 individuals remained still after autotomy, 1 hovered within its own ink cloud. T erminal photophores on all the autotomized arms were white (i.e. bioluminescent) while visible on the ROV camera feed screen. Some of the autotomized ar ms $(n=4)$ remained attached to the bottle-br ush by the hooks near the site of autotomy . In 2 cases, the distal, fr ee end thrashed, in 2 others it did not thrash. $\mathrm{T}$ wice an autotomized arm (1 each fr om 2 individuals) detached from the bottle-brush soon after autotomy;
1 thrashed for $47 \mathrm{~s}$, while the other thrashed for $10 \mathrm{~s}$ before going out of sight.

\section{DISCUSSION}

Like many animal species, Octopoteuthis deletron has a series of defenses that escalate from primary to secondary (Edmunds 1974). Primar y defenses in clude crypsis and polyphenism, while the secondary defenses of deflection, jet-escape, ink $\mathrm{r}$ elease, and startling with bioluminescence come into play when primary defenses fail (Edmunds 1974, Her ring 2002, Bush et al. 2009). O. deletron is the first squid species reported to autotomize its ar $\mathrm{ms}$, and each of the 8 arms is capable of doing so. Multiple ar ms can be autotomized at once, presumably enhancing the distraction of a potential pr edator and incr easing the likelihood of the squid's escape. Additionally, if 1 or a few arms are autotomized, the other arms can still be autotomized during another defensive interaction. The fact that fractur e planes wer e only obser ved in 2 of 15 individuals likely indicates that autotomy in $O$. deletron occurs at potential, instead of pr eformed, sites of weakness.

The ability to regenerate the arms may allow autotomy to be used as a defense r epeatedly given sufficient time. A specimen with all ar ms autotomized was collected by ROV and kept alive in the laboratory for several days. A few of the ar ms regenerated up to $2 \mathrm{~mm}$ of tissue after $9 \mathrm{~d}$ at 4 to $6^{\circ} \mathrm{C}(\mathrm{H}$. J. Hoving $\&$ M. Powers pers. comm.). The habitat temperatur e of this species is $\sim 2$ to $8^{\circ} \mathrm{C}$ (Bush et al. 2009), and, though I do not know typical gr owth rates for Octopoteuthis deletron, if this rate is representative, it indicates that regeneration may be relatively rapid.

Defensive autotomy has numer ous costs, such as reduced growth and decreased fecundity, as the animal must allocate ener gy to regenerating the autotomized tissue (Maginnis 2006, Fleming et al. 2007, Lawrence 2010). Previous studies have shown preferential investment in $r$ egeneration of autotomized tissue over contributions to nutrient reserves, and increased metabolic rates during $r$ egeneration (Lawrence \& Larrain 1994, Naya \& Bozinovic 2006). Deepsea species must balance these $r$ equirements with the demands of living in a habitat where food is limited and potentially har d to find, and an or ganism must maintain neutral buoyancy or swim constantly (Herring 2002, Robison 2004). Additionally, Octopoteuthis deletron has been proposed to use the terminal photophores as lures for potential prey or to signal to conspecifics, so the loss of these photophor es 
resulting from arm autotomy could make pr enticement or mate attraction and signaling less effective (Bush et al. 2009). Similarly, subduing and handling prey may be less ef fective without 8 fully intact arms (Ramsay et al. 2001).

To counteract some of these costs, Octopoteuthis deletron demonstrates 'economy of autotomy' — breakage occurs just proximal to where the arm is grasped or where the arm hooks hold onto an object (Bustard 1968). Economy of autotomy is r elatively uncommon among animals that autotomize, though it occurs in some clams, seastars, brittlestars, crinoids, and lizards (Delage \& Herouard 1903, Gilmour 1963, Bustard 1968, McVean 1975). Economy of autotomy has the clear advantage of minimizing tissue loss, and thereby reducing the associated costs of this defense, while still allowing escape (Delage \& Herouard 1903, Fleming et al. 2007). O. deletron is the first cephalopod species r eported to be capable of economy of autotomy.

Attack autotomy was first documented in crabs, which grip potential pr edators with the claw, and then autotomize it (Robinson et al. 1970, McV ean 1975). Octopoteuthis deletron is the only other species known to perform attack autotomy, which likely startles or distracts the predator as the squid grabs it, and then the autotomized arm or arms may begin to thrash and bioluminesce. After autotomization, individuals sometimes moved rapidly away . However, escape is energetically expensive and may stimulate environmental bioluminescence, allowing a predator to follow the squid (W idder et al. 1989, Seibel et al. 2000, Robison et al. 2003). Perhaps for these reasons, $O$. deletron has been observed to remain motionless after in situ autotomy, sometimes within an ink cloud. The latter has been obser ved in a number of other deep-sea squids (Vecchione et al. 2002, Bush \& Robison 2007).

The movement of the thrashing arms will stimulate additional bioluminescence in the sur rounding water, and pr obably increase the predator's attention (Widder et al. 1989). The use of bioluminescent appendages or secr etions as a defensive distraction has been obser ved in many deep-sea animals, in cluding jellies, polychaetes, cr ustaceans, and the cephalopod Vampyroteuthis infernalis (Herring 2002, Robison et al. 2003, Osbor n et al. 2009, Haddock et al. 2010). Likely ther e are additional species to be discovered using similar tactics.

Mesopelagic animals face many challenges in their large, 3-dimensional habitat wher e both food and mates may be few and far between (Her ring 2000). The use of bioluminescence to signal to potential mates or attract prey is common in the deep sea (Her ring 2000). This will also attract pr edators, however, and, once detected, a midwater animal has nowher e to hide and must avoid being attacked by distracting the predator or attempting escape. The postur e in which Octopoteuthis deletron is typically first ob served by a ROV - with the body horizontal and the arms positioned $90^{\circ}$ to the body axis or $r$ eaching backward over the mantle (arms parallel to the body axis; see Bush et al. 2009), while the photophor es luminesce on and of $\mathrm{f}$ - may divert attention away from the head and body to the sacrificial ams, giving O. deletron an effective defensive strategy against a diversity of predators (Clarke 1996, Croxall \& Prince 1996, Klages 1996, Smale 1996).

Acknowledgements. This work was only possible thr ough the assistance and support of many people at the Monter ey Bay Aquarium Research Institute, especially the Midwater Ecology team, including K. Reisenbichler , R. Sherlock, K. Osborn, C. Huf fard, and most notably B. Robison. S. Haddock made workspace available to me, both on land and at sea. S. Von Thun and the MBARI Video Lab provided at-sea support and digitized many obser vation sequences fr om ROV video. H. J. Hoving and M. Powers shared their observations of Octopoteuthis deletron. R. Caldwell pr ovided encouragement and advice throughout the project. B. Fisher and colleagues at the Community Hospital of Monter ey Peninsula performed histology. B. Seibel, A. Maas, and D. Greenwood read drafts of the manuscript, and N. Blouin and D. Chappell helped with figures. The clarity of the manuscript was impr oved by reviewer suggestions. This work was financially supported by the David and Lucile Packar d Foundation's funding to MBARI and a National Science Foundation Graduate Research Fellowship to the author.

\section{LITERATURE CITED}

Bush SL, Robison BH (2007) Ink utilization by mesopelagic squid. Mar Biol 152:485-494

Bush SL, Robison BH, Caldwell RL (2009) Behaving in the dark: locomotor, chromatic, postural, and bioluminescent behaviors of the deep-sea squid Octopoteuthis deletron Young, 1972. Biol Bull 216:7-22

Bustard HR (1968) Temperature dependent tail autotomy mechanism in gekkonid lizar ds. Herpetologica 24: $127-130$

- Clarke MR (1996) Cephalopods as pr ey. III. Cetaceans. Philos Trans R Soc Lond B 351:1053-1065

Croxall JP, Prince PA (1996) Cephalopods as pr ey. I. Seabirds. Philos Trans R Soc Lond B 351:1023-1043

Delage Y, Herouard EJE (1903) Traité de zoologie concrète. Tome III. Les échinodermes. Schleicher Freres, Paris

Edmunds M (1974) Defence in animals: a sur vey of antipredator defences. Longman Group, Essex

> Endler JA (1981) An overview of the relationships between mimicry and crypsis. Biol J Linn Soc 16:25-31

Fleming PA, Muller D, Bateman PW (2007) Leave it all behind: a taxonomic perspective of autotomy in inver tebrates. Biol Rev Camb Philos Soc 82:481-510

Gilmour THJ (1963) A note on the tentacles of Lima hians 
(Gmelin) (Bivalvia). J Molluscan Stud 35:82-85

Haddock SHD, Moline MA, Case JF (2010) Bioluminescence in the sea. Annu Rev Mar Sci 2:443-493

Herring PJ (2000) Species abundance, sexual encounter and bioluminescent signalling in the deep sea. Philos Trans R Soc Lond B 355:1273-1276

Herring PJ (2002) The biology of the deep ocean. Oxfor d University Press, Oxford

Hochberg FG, Norman MD, Finn J (2006) Wunderpus photogenicus n. gen. and sp., a new octopus fr om the shallow waters of the Indo-Malayan Ar chipelago (Cephalopoda: Octopodidae). Molluscan Res 26:128-140

Huffard CL (2007) Ethogram of Abdopus aculeatus (D'Orbigny, 1834) (Cephalopoda: Octopodidae): Can behavioral characters inform octopodid taxonomy and systematics? J Molluscan Stud 73:185-193

Klages NTW (1996) Cephalopods as pr ey. II. Seals. Philos Trans R Soc Lond B 351:1045-1052

Lawrence JM (2010) Energetic costs of loss and r egeneration of ar ms in stellate echinoder ms. Integr Comp Biol 50:506-514

- Lawrence JM, Larrain A (1994) The cost of arm autotomy in the starfish Stichaster striatus. Mar Ecol Prog Ser 109: 311-313

> Maginnis TL (2006) The costs of autotomy and regeneration in animals: a review and framework for future research. Behav Ecol 17:857-872

- McVean A (1975) Autotomy. Comp Biochem Physiol A 51:497-505

Naef A (1923) Cephalopoda. Fauna e flora del Golfo di Napoli. Monograph 35 (translated fr om German by the Israeli program for scientific translations, Jer usalem, in 1972). Friedländer, Berlin

- Naya DE, Bozinovic F (2006) The role of ecological inter actions on the physiological flexibility of lizar ds. Funct Ecol 20:601-608

Naya DE, Veloso C, Munoz JLP, Bozinovic F (2007) Some vaguely explored (but not trivial) costs of tail autotomy in lizards. Comp Biochem Physiol A 146:189-193

$>$ Norman MD (1992) Ameloctopus litoralis gen. et sp. nov . (Cephalopoda: Octopodidae), a new shallow-water octopus from tropical Australian waters. Invertebr Taxon 6:567-582

Norman MD, Finn J (2001) Revision of the Octopus horridus species-group, including erection of a new subgenus and description of two member species fr om the Great Barrier Reef, Australia. Invertebr Taxon 15:13-35

Norman MD, Hochberg FG (2005) The 'mimic octopus' (Thaumoctopus mimicus n. gen. et sp.), a new octopus from the tr opical Indo-West Pacific (Cephalopoda: Octopodidae). Molluscan Res 25:57-70

> Norman MD, Paul D, Finn J, Tregenza T (2002) First en counter with a live male blanket octopus: the world' $\mathrm{s}$ most sexually size-dimorphic lar ge animal. NZ J Mar Freshw Res 36:733-736

> Osborn KJ, Haddock SHD, Fredrik P, Madin LP, Rouse GW (2009) Deep-sea, swimming wor ms with luminescent 'bombs'. Science 325:964

Ramsay K, Kaiser MJ, Richardson CA (2001) Invest in arms: behavioural and energetic implications of multiple auto-

Editorial responsibility: Matthias Seaman,

Oldendorf/Luhe, Germany tomy in starfish (Asterias rubens). Behav Ecol Sociobiol 50:360-365

Robinson MH, Abele LG, Robinson B (1970) Attack autotomy: a defense against pr edators. Science 169:300-301

$>$ Robison BH (2004) Deep pelagic biology . J Exp Mar Biol Ecol 300:253-272

Robison $\mathrm{BH}$, Reisenbichler KR, Hunt JC, Haddock SHD (2003) Light production by the arm tips of the deep-sea cephalopod Vampyroteuthis infernalis. Biol Bull 205: 102-109

Roper CFE, Sweeney MJ, Nauen CE (1984) FAO species catalogue, Vol 3. Cephalopods of the world: an annotated and illustrated catalogue of species of inter est to fisheries. FAO Fish Symp 125:1-277

> Seibel BA, Thuesen EV, Childress JJ (2000) Light-limitation on predator-prey interactions: consequences for metabolism and locomotion of deep-sea cephalopods. Biol Bull 198:284-298

Smale MJ (1996) Cephalopods as pr ey. IV. Fishes. Philos Trans R Soc Lond B 351:1067-1081

Strugnell J, Jackson J, Drummond AJ, Cooper A (2006) Divergence time estimates for major cephalopod groups: evidence from multiple genes. Cladistics 22:89-96

> Sweeney MJ, Roper CFE, Mangold KM, Clarke MR, Boletzky Sv (1992) 'Lar val' and juvenile cephalopods: a manual for their identification. Smithson Contrib Zool 513:1-282

Thomas RF (1977) Systematics, distribution, and biology of cephalopods of the genus Tremoctopus (Octopoda: Tremoctopodidae). Bull Mar Sci 27:353-392

Vecchione M, Roper CFE, Widder EA, Frank TM (2002) In situ observations on three species of lar ge-finned deepsea squids. Bull Mar Sci 71:893-901

Ward LA (1998) Octopus brachiotomus sp. nov. (Cephalopoda: Octopodidae), a new shallow-water , arm autotomizing octopus from Guam; and arm autotomy in Octopus brachiotomus from Guam. MS thesis, University of Guam, Mangilao

Widder EA, Bernstein SA, Bracher DF, Case JF, Reisenbicher KR, Torres JJ, Robison BH (1989) Bioluminescence in the Monterey Submarine Canyon: image analysis of video $r$ ecordings from a midwater submersible. Mar Biol 100:541-551

Wilkie IC (2001) Autotomy as a pr elude to regeneration in echinoderms. Microsc Res Tech 55:369-396

Wilkie IC, Griffiths GVR, Glennie SF (1990) Morphological and physiological aspects of the autotomy plane in the aboral integument of Asterias rubens L. In: De Ridder CP, Dubois P, LaHaye MC, Jangoux M (eds) Echinoder m research. Balkema, Rotterdam

> Wrinn KM, Uetz GW (2008) Effects of autotomy and regeneration on detection and captur e of prey in a generalist predator. Behav Ecol 19:1282-1288

Young RE (1972) The systematics and aerial distribution of pelagic cephalopods from the seas of $f$ southern California. Smithson Contrib Zool 97:1-159

Young RE, Vecchione M (2009) Octopoteuthis Ruppell, 1844, Version 29, December 2009. The tr ee of life web project. Available at: http://tolwebor g/Octopoteuthis/ 19839/20091229 (accessed October 20, 2011)

Submitted: October 26, 2011; Accepted: March 8, 2012

Proofs received from author(s): June 18, 2012 